\title{
ON MULTIPLE BROODS AND THE BREEDING STRATEGY OF ARCTIC SANDERLINGS
}

\author{
D. F. Parmelee \& R. B. Payne
}

Received on 22 December 1971

The sandpipers nesting in the arctic generally lay a single clutch of four eggs during the brief northern summer. Biologists working in the far north have been greatly impressed with the briefness of the growing season and the period during which the summering waders lay their eggs (Pitelka 1959, Parmelee \& MacDonald 1960, Parmelee, Stephens \& Schmidt 1967, Boyd 1962, Holmes 1966, 1970, Matthiessen, in Stout 1967, Lack 1968). A few northern waders lay a second clutch if the first one is lost, but the fairly long delay between the loss of the first and the laying of the second (Holmes 1966) indicates a serious problem of storing sufficient nutrients for the formation of another set of eggs. The shortness of the arctic summer with fluctuating food supplies would seem to preclude any breeding strategy in the small waders other than laying a single clutch of large eggs and rearing a single brood during any one breeding season.

During a field study of Sanderlings Calidris alba on Bathurst Island at $75^{\circ} 48^{\prime} \mathrm{N}$ latitude in the Canadian high arctic in 1968 and 1969, Parmelee came to suspect that these waders sometimes lay more than one clutch in a season, the second clutch being not merely a replacement of an earlier one lost to predators or the weather, but rather a case of true multiple broodedness. In 1970, on the Bathurst breeding ground, he collected two incubating female Sanderlings and preserved their ovaries. The examination of these ovaries by Payne indicates the laying of two clutches in rapid succession.

The multiple layings of Sanderlings appear to be an important part of an adaptive strategy for exploitation of an environment that varies considerably from year to year. Behaviour related to multiple broods in Sanderlings includes the active role of courting females, incubation by either sex, and also, we suspect, occasional polyandry.

\section{FIELD OBSERVATIONS}

Sanderlings arrive on their northern breeding grounds on Bathurst Island early in June. Although some males begin to perform aerial displays within a few days of their arrival, egg-laying is delayed for some time, probably because of the unavailability of suitable feeding ponds early in the season. Copulation was seen from 22 to 26 June in 1968 and from 18 to 25 June in 1969 . The eggs were laid between 21 June and 2 July in 1968-1970, in the four nests on which the date of laying was known directly. Fourteen other nests were discovered between 27 June and 14 July after all four eggs had been laid and the birds were incubating. The dates of laying and of incubating as well as the dates of young just beginning to fly (Parmelee 1970: 139) suggest a laying season of at least two weeks for the Bathurst population as a whole. By means of selective collecting, ringing and colour marking of nesting adults, and of observing their nests (including a continuous, round-the-clock watch at one), it was found that only a single individual incubates at any one nest and that one bird alone later attends the brood. Some nests are incubated by the female, others by the male.

The observation that led us to suspect Sanderling females might lay two clutches in rapid succession was the delay between laying and the onset of incubation at a nest (no. 13 ) in 1969. Selection of the nest cup by the female and the laying of each of her four eggs at 26- to 28-hour intervals were observed (Parmelee 1970: 119-120). After laying the last egg, the female flew off and was not seen again. Her mate, which had been banded 
the previous year, had been seen at nest 13 before the first eggs were laid, but he had disappeared just before egg laying. Five days and 16 hours after completion of the clutch he suddenly returned to nest 13 and began incubating. The long period between completion of the clutch by the female and start of incubation by the male seemed extraordinary in view of the high latitude and severe climatic conditions of Bathurst Island. Parmelee suspected that during the nearly six-day absence from nest 13 the birds were attempting another nesting on another site. The delay in the start of incubation at nest 13 was in part responsible for the long incubation period (from laying to hatching of last egg) of 31 days 16 hours, far longer than the 24 days 6 hours at another Bathurst nest in 1968.

In 1970 we were unable to show directly by means of banded birds that any Sanderlings had two nests, but other field data collected that year further support the idea that Sanderlings may have more than one nest in a season. At one nest (no. 16), where the third egg was laid on 27 June, Parmelee succeeded in capturing the pair. On 28 June the male evinced so much interest in the nest that he ran in and sat on the three eggs several times before finally being caught, banded, colour marked, and released. The female was caught a short time later when she went in to lay her fourth egg. She was marked and released at once and soon returned to the nest and laid. After laying, she ran off and was not seen again, though an intensive search was made. The male commenced steady incubation within two hours of the laying of the fourth egg. The incubation period for the last egg laid was 24 days 16 hours.

At another nest (no. 17), where no male was observed, Parmelee saw the laying of the third egg on 2 July. The following day he caught the female when she went to the nest to lay. Soon after she was marked and released, she ran back to the nest and laid her fourth egg. Ten hours later she was on the eggs, and she incubated steadily from that time onward. The precise incubation period for eggs in this nest was not determined, but it was close to 24 days, judging by the time interval from starring of the shell to hatching at other Sanderling nests. One of the four eggs was starred when last seen 19 days after completion of the clutch. Whether this female had laid earlier in the season is unknown.

These observations make clear that after completion of a clutch, the male may start to incubate immediately, or he may abandon the clutch temporarily. The observations further suggest that there are two kinds of nests, those that are incubated by either sex with no delay after completion of the clutch, and those at which incubation by males begins only after approximately the number of days that would be required to complete a second clutch at another nest. As it has proven extremely difficult to follow a marked Sanderling away from its nest, the best available evidence for the occurrence of rapid multiple layings in females comes from examination of their ovaries.

\section{OVARIES OF SANDERLINGS}

On Bathurst Island in 1970 two female Sanderlings were taken from their nests and their ovaries preserved. One bird, collected on 30 June at $22.30 \mathrm{hrs}$, seemed unusually reluctant to leave the nest, which held four eggs with minute embryos no older than about two or three days. The other, collected on 4 July at $23.45 \mathrm{hrs}$, was reluctant to return to the nest when flushed, and its four eggs were fresh. Neither of the two females had been marked; both were taken on the day that their nests were discovered.

The ovaries of the two specimens were preserved in $10 \%$ formalin and were later examined under a dissecting microscope. In both ovaries were seen eight yellowish, bag-like elongated or folded structures identified as post-ovulatory follicles, the tissue that had held the yolk as it was being formed in the ovary. Both females had evidently already laid two complete clutches. Each of the ruptured follicles had a slit-like opening visible at the end farthest from the attachment of the follicle to the body of the ovary; the slit was usually occluded with a mass of yellowish or creamy material. The presence of the slit indicated that each of these follicles had ovulated. 
To ascertain whether each of the follicles examined in the intact ovary had in fact ruptured in ovulation, the ventral and dorsal surfaces of the ovaries were sketched and photographed. After the follicles (ovulated, growing, and atretic) were measured, the ovaries were embedded in paraffin, and the smaller one (4 July) was serially sectioned at 6-8 $\mu$ to check the identification of the ovulated follicles. The sections were stained with hematoxylin and eosin, each section was examined microscopically, and all of the structures that had been identified in the intact ovary as ruptured, atretic, or growing ovarian follicles were located by referring to the earlier sketches and photographs of the ovary. Each of the presumptive post-ovulatory follicles showed clearly an opening from the lumen through the theca and the ovarian epithelium.

The following section describes each of the ovaries and discusses the structures identified as ovulated follicles in Plates 3-5.

The ovary collected on 30 June had five yolky, yellow follicles. From their size it is likely that some of these would have ovulated within a few days. The sizes of the rounded, yolky follicles and of the other large follicles are listed in Table 1. The large A-follicle at $6.0 \mathrm{~mm}$ was about the size of an icterid blackbird (Agelaius tricolor or $A$. phoeniceus) ovarian follicle 1-2 days before ovulation or 2-3 days before laying (Payne 1969: 52), and while blackbirds and sandpipers are unrelated their eggs are about the same size (mean size of Sanderling eggs is $35.7 \times 24.7 \mathrm{~mm}$, Bent 1927: 269; mean size of A. tricolor eggs is $27.7 \times 20.4 \mathrm{~mm}$, Bent 1958: 184). The six largest follicles graded smoothly in size from 6.0 to $3.6 \mathrm{~mm}$, and differential growth of follicles leading to the sandpiper clutch of four would probably have taken place over the next few days. In the ovary also were eight post-ovulatory follicles, each with an ovulation slit clearly visible at the end. The eight formed a series ranging from 5.5 to $2.0 \mathrm{~mm}$ and no break in size between the four largest and the four smallest was readily apparent (Table 1), suggesting

TABLE 1

Follicle sizes in the ovaries of two Sanderlings after ovulation of two clutches

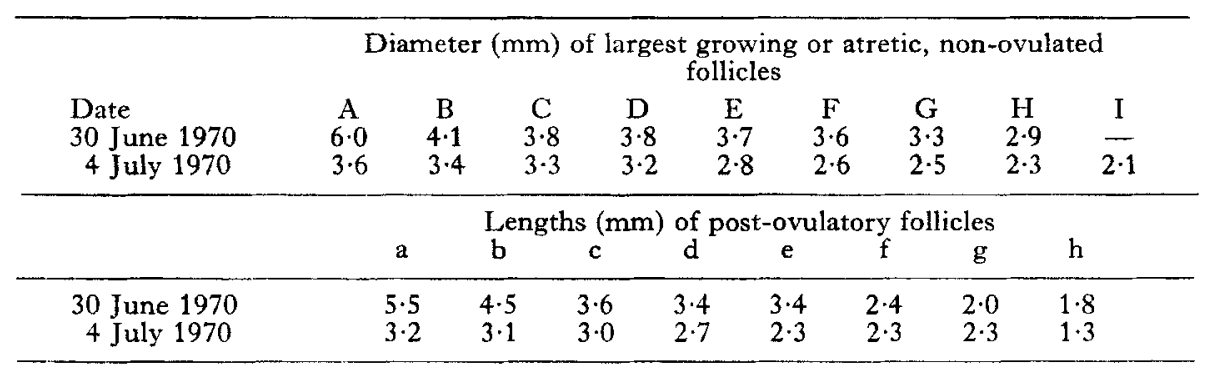

that no more than a few (probably two or three) days had elapsed between the laying of the last egg of the earlier clutch (represented by the four small post-ovulatory follicles) and the laying of the first egg of the second clutch (represented by the four larger ovulated follicles). The four largest (more recent) ovulated follicles (a, b, c, d) were attached to the ovary near its posterior end and were more or less clustered together. The other four $(e, f, g, h)$ were less closely clustered and had perhaps been shoved aside by the more recent development and growth of the ovarian follicles between them. The post-ovulatory follicles appeared in formalin solution to have two layers, a relatively clear, whitish, translucent outer layer and an opaque, yellowish core; this was less apparent in the photographs made when the ovary was stored in ethanol. One of the apparently ruptured follicles in this ovary (e) departed slightly from the usual shape of recently ovulated follicles; it was wrinkled on the dorsal surface and could possibly have been a follicle that did not ovulate normally but 


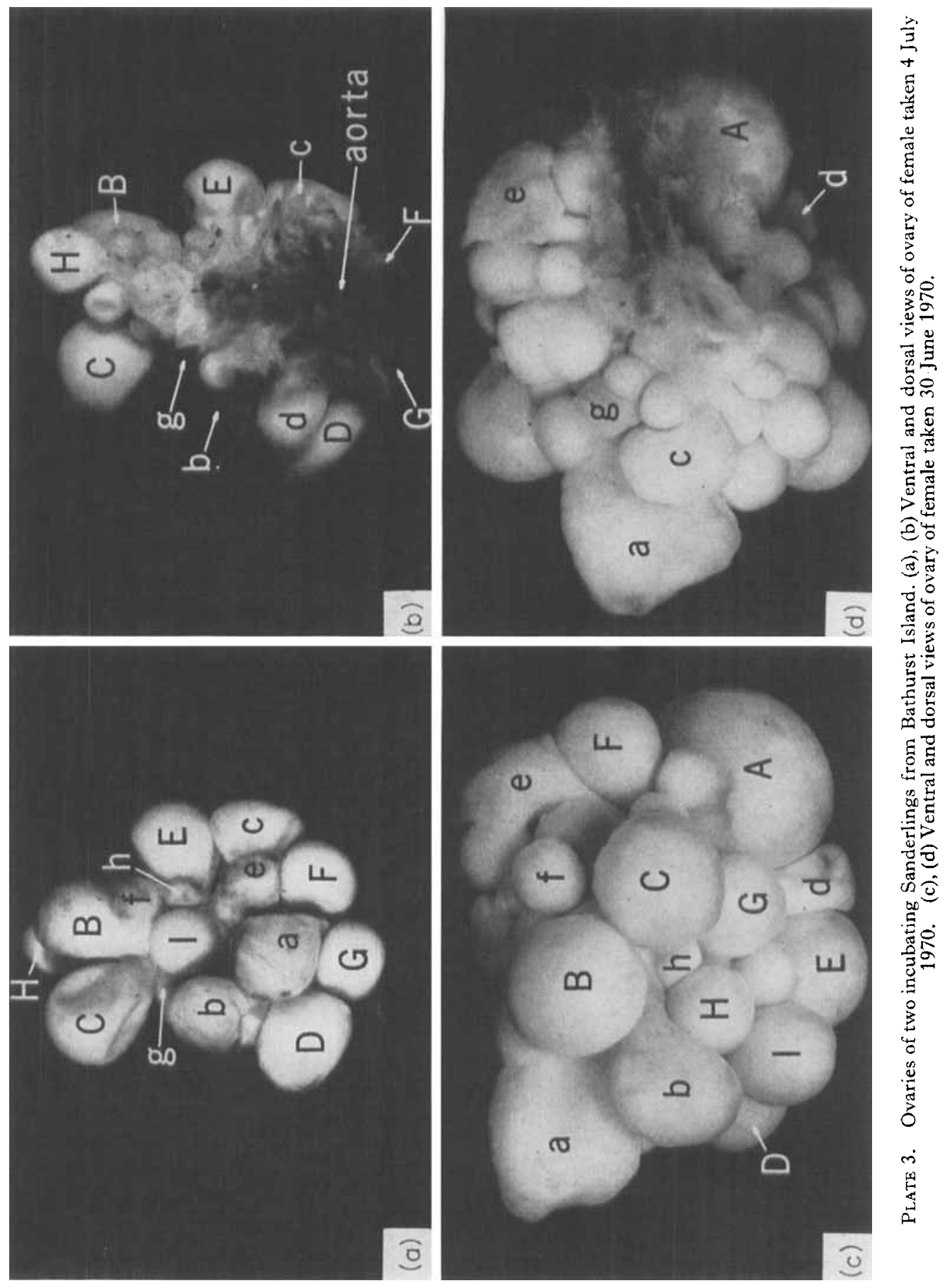


PLATE 4

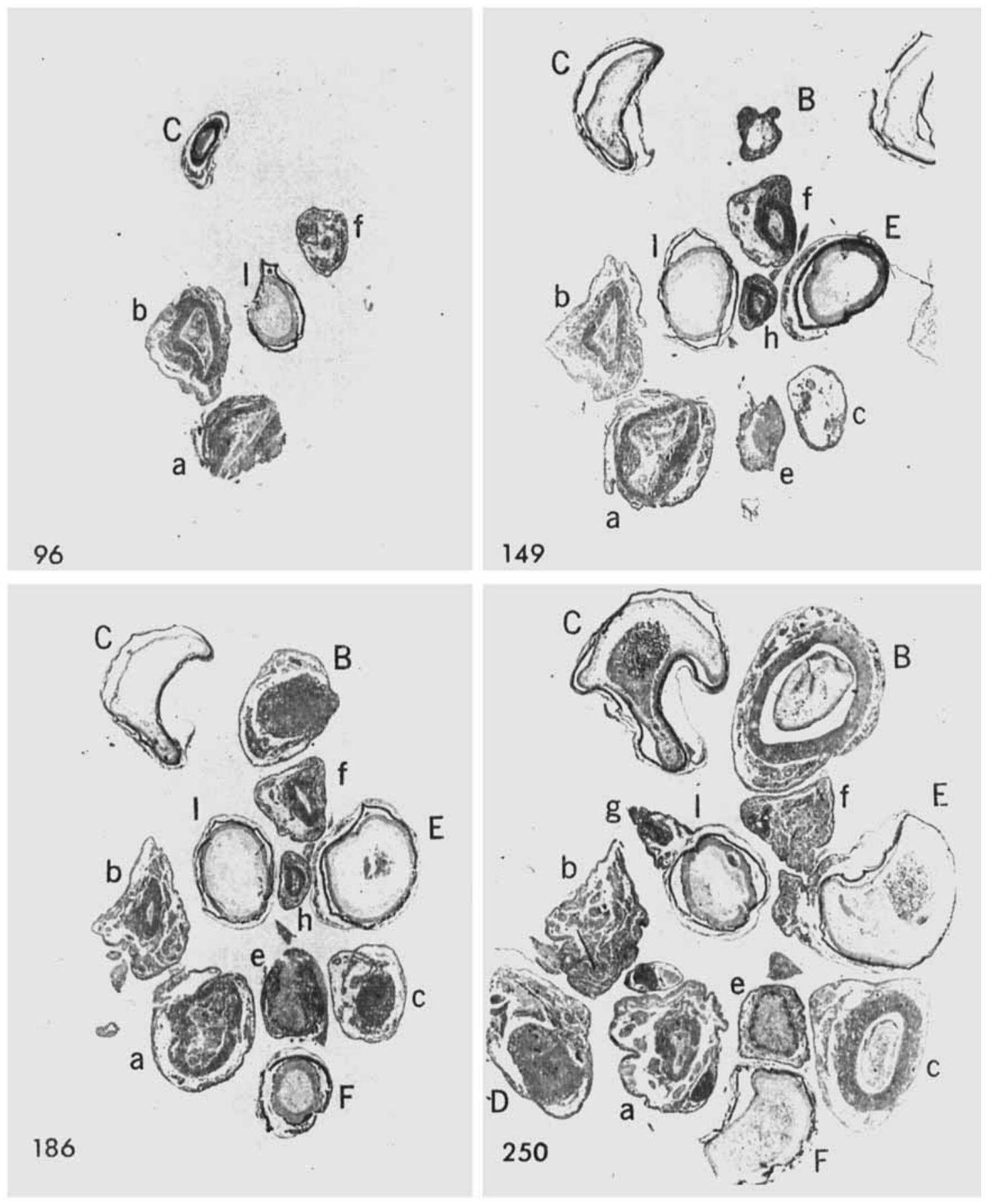

Plate 4. Serial sections of ventral half of Sanderling ovary taken 4 July 1970 . Numbers refer to the section number, large letters identify growing follicles, and small letters indicate post-ovulatory follicles. 


\section{PLATE 5}

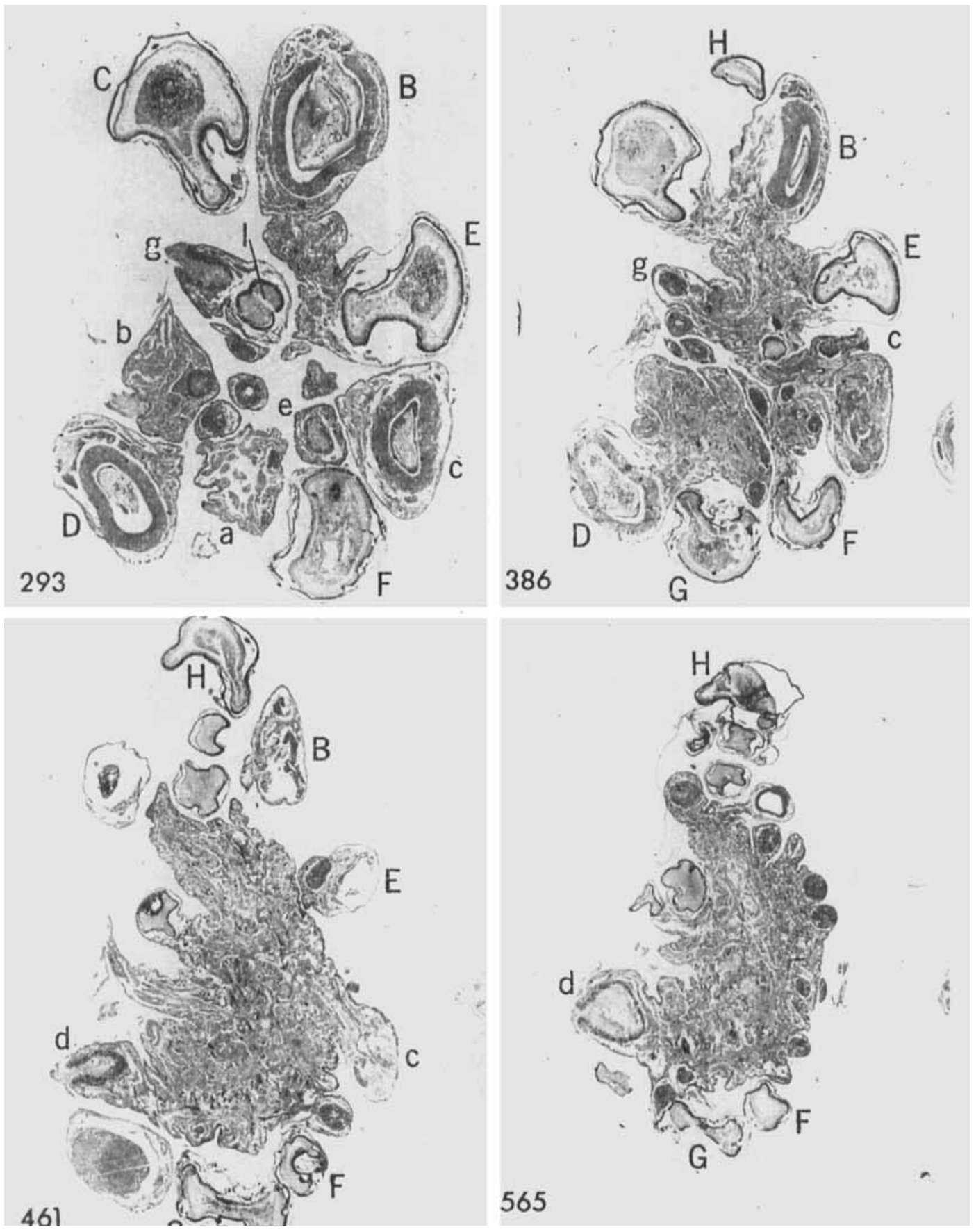

PLATE 5. Serial sections of dorsal half of Sanderling ovary taken 4 July 1970. Numbers refer to the section number, large letters identify growing follicles, and small letters indicate post-ovulatory follicles. 

became atretic, burst its vitelline membrane, and spewed yolk through the connective tissue layer beneath the ovarian epithelium. The other three follicles of this set had ovulated normally. The size gradation $(5.5 \mathrm{~mm}$ to $2.0 \mathrm{~mm})$ in the series of eight ruptured follicles is close to the gradation in size of blackbird post-ovulatory follicles (Payne 1966: 333 ) in the eight days following ovulation, and the Sanderling follicles probably represent a group of eight eggs laid in rapid succession in 8-10 days. From Parmelee's field observations it is known that Sanderlings eggs are laid on successive days at intervals of 26-29 hours, and this time interval suggests that the ageing of the Sanderling follicles by their size and histology is reasonably accurate.

In summary, the 30 June ovary of a Bathurst Island Sanderling shows clear evidence of the rapid ovulation of two clutches and the development of yolky eggs for a third possible clutch as well.

The 4 July ovary was smaller and had no large, yolky follicles; the largest ovarian follicle was $3.6 \mathrm{~mm}$. This follicle is included in Table 1 but it was separated from the ovary during dehydration and is lacking in Plate 3. Most of the ovulated follicles lay on the ventral surface of the ovary and also were grouped together. The ovulated follicles of this ovary also showed a sparse speckling of blackish particles near the surface; these are barely visible in Plate 3, which shows also the pale, avascular area on either side of the ovulation slit. Growing follicles B and C were somewhat collapsed, an artifact of shrinkage caused by dehydration; these follicles were fully rounded while in formalin solution. Follicle $\mathrm{H}$ was lumpy and had an opaque core and dark pigment on the surface, but as it had no ovulation slit visible it was identified as an atretic follicle. The post-ovulatory follicles formed a graded series with the largest one only slightly longer than the next (Table 1). No sharp break in size was apparent between the fourth (d) and fifth (e) smallest ruptured follicles, indicating that no more than two or three days had elapsed between the end of the first clutch of four eggs and the laying of the second.

To confirm the identification of the post-ovulatory follicles, serial sections of the ovary were made in a plane approximately parallel to its ventral surface, so that the sections could be compared readily with the sketches and photographs. The histological appearance of post-ovulatory follicles (POF) in several kinds of birds has been described by Fell (1925), Davis (1942), Dominic (1959), Payne (1966), and Erpino (1969). These ovulated follicles are distinguished histologically by shape (irregular, elongate, or angular, rather than round), the correspondingly irregular shape of the lumen, the close association of the granulosa cells with the basement membrane in early stages of regression, the lack of yolk, widespread necrosis and invasion of phagocytes and fibroblasts, and the folded appearance of the theca. Post-ovulatory follicles often quickly fill with necrotic, sloughed granulosa cells and phagocytes, and in a few days these occlude the lumen and migrate back out between the inner theca and the outer layer of epithelium and connective tissue surrounding the ovary. Follicles in this stage of regression are characterised by a translucent, watery outer layer (containing the tissue fluid and migrating phagocytes) and a dense, opaque, often yellowish-pigmented inner layer of necrotic tissue and the surrounding thecal wall (Payne 1966). It is sometimes necessary to section each structure to determine whether ovulation has occurred or whether the yolk has ruptured within the follicle and burst out through the theca, spewing yolk into the loose surrounding connective tissue, as described by Erpino (1969). The post-ovulatory follicles quickly shrink and disintegrate and can be followed clearly for no more than about two weeks after ovulation; after that time they become histologically indistinguishable from some regressed atretic follicles.

The histological structures corresponding to the yolky, atretic, and post-ovulatory follicles identified in the 4 July Sanderling ovary are shown in a series of photomicrographs (Plates 4, and 5). Representative sections at intervals of $0.6 \mathrm{~mm}$ or less through the ovary are shown to permit comparison of sections through a single follicle at several points and to 
document the eight post-ovulatory follicles. The labelled ovulated follicles in section may be compared with their appearance in the photograph of the intact ovary. The sections selected were chosen to show each post-ovulatory follicle at the point of ovulation (though some follicles are secondarily plugged with macrophages and degenerating granulosa cells) to establish that the follicle had ovulated. The sections are described in sequence below.

Section 96. Ovulated follicles a and $\mathrm{b}$ are evident, with the opening in $\mathrm{b}$ shown better in more ventral sections and in the intact ovary.

Section 149. Taken dorsal to section 96 , this section shows post-ovulatory follicles $a$ and $b$ past their ovulation slit; the lumina are full of debris, the outer layer of connective tissue is pulling away from the theca, and phagocytic cells are migrating back in this swollen space (the translucent layer of the intact ovary). Other ovulated follicles $(c, e, f, h)$ and growing follicles appear in this section.

Section 186. Post-ovulatory follicle e is open to the exterior through the ovulation slit, the lip of $e$ on the right has been pulled out and back and is everted apparently by the outer contractile layer of connective tissue of the follicle wall. Post-ovulatory follicles $f$ and $h$ each show a swollen, oedematous outer layer and a more dense, cellular core. Connective tissue of atretic follicle $\mathbf{B}$ appears in nearly-tangential section through its ventral wall.

Section 250. Note the thick, hyperplastic wall of atretic follicle $B$ and the darkly-staining, folded vitelline membrane and the yolk granules inside the lumen. Post-ovulatory follicle $f$ is cut in a plane parallel with its surface shown in Plate 3 and is opening to the outside. The outer and inner layers of POF $\mathrm{c}$ are apparent. The ventral edge of POF $\mathrm{g}$ is just appearing near growing follicle I.

Section 293. Yolky atretic follicle B here has burst through the theca and spilled yolk and viteiline membrane into the space between the ovarian epithelium and the theca, but the epithelium has remained intact, and the follicle has not ovulated. Yolk and phagocytes appear in the outer space between the epithelium and its dense connective tissue and the inner theca. Post-ovulatory follicle $\mathrm{g}$ is opening to the outside. Post-ovulatory follicles $\mathrm{a}$ and $\mathrm{b}$ are now unrecognisable as POF in this section and are evident only by the oedematous connective tissue at their bases. Follicle $\mathrm{C}$ is misshapen from the shrinkage of dehydration.

Section 386. The opening of post-ovulatory follicle $\mathrm{c}$ is at its posterior edge. Most of the ovary in this section is composed of vascular connective tissue, a few darkly-staining small atretic follicles are also apparent.

Section 461. Most of the ovary dorsal to this section is composed of connective tissue. Postovulatory follicle $\mathrm{d}$ (which was dorsal to most of follicle $\mathrm{D}$ ) is appearing and its opening is visible.

Section 565. Post-ovulatory follicle $\mathrm{d}$ is cut through its mid-point in this section which shows the opening of the POF still visible whence its yolk had ovulated. The body of the ovary is becoming smaller as the sections approach its dorsal side.

As the serial sections of the Sanderling ovary showed that the structures identified as ovulated follicles by their bag-like shape, two layers, yellowish centre, and visible ovulation slit were histologically similar to the post-ovulatory follicles of other birds, it is clear that arctic Sanderlings sometimes may lay two clutches in little more than a week. The histological characters suggest that laying of two clutches took no more than about 10 days though as POFs can be aged only within about 20 or $30 \%$ accuracy (Payne 1966), it was not possible to estimate the time interval between the two clutches more precisely than from one to four days.

\section{DISCUSSION}

Sanderlings appear to be remarkably similar in their breeding biology to Temminck's Stint Calidris temminckii, a small sandpiper breeding in the moors and tundra of the Old World. Hilden (1965) discovered that female Temminck's Stints often lay two clutches; he has traced a marked female to two successive nests. The male stint often waits for several days after the early clutch is completed before he begins to incubate. For several days after the first clutch is laid he consorts with the female, apparently competing with other males for the opportunity to mate with her and to fertilise a second set of eggs. The interval between clutches is $2-4$ days, and during this time some females associate with two males. Usually the female incubates the second clutch which is laid far from the early one. Incubating females have been taken at about half of the completed clutches and 
males at the others; rarely are both male and female Temminck's Stints taken with a single brood. Evidently this kind of behaviour is rare in waders and has not been reported for other species of calidrine sandpipers, although Nethersole-Thompson \& NethersoleThompson (in Bannerman 1961: 247) noted the occasional occurrence of biandry in a population of Dotterel Eudromias morinellus breeding in Scotland.

Both Temminck's Stints and Sanderlings have unusually small eggs in relation to body size compared to most other small waders (Schönwetter 1966, Lack 1968), and the reproductive effort of forming each clutch and the risks attendant to the female are probably smaller by comparison. The Little Stint Calidris minuta is similar in body size to Temminck's Stint and breeds even further north, on the average; egg-weights and breeding biology studies are not available, but egg measurements are slightly larger than in Temminck's Stint and, according to Dement'ev, Gladkov \& Spangenberg (1969), both sexes are said to incubate and to care for the young (in different clutches?). Perhaps some closely related Calidris species nesting in arctic Siberia have similar breeding biologies.

Sanderlings for the most part breed in the high arctic where climatic conditions are severe and often extremely variable from year to year. Favourable weather early in the season often results in a highly favourable year for breeding birds; unfavourable weather persisting into late June and July often results in a retarded season or one in which many birds fail to breed successfully, if they breed at all. Conditions locally are so poor at times that few breeding and feeding areas are free of ice and snow early in the season and, at least on Bathurst Island, these are not necessarily the same ones every year. It would appear that Sanderlings respond to these annual differences by laying more than one clutch in good years and by laying only one or none at all in poor years. By varying the number of clutches, Sanderlings appear to be opportunistic, individual birds being able to alter their reproductive effort to accommodate local field conditions. The production of more than one brood during the short nesting season of the high arctic is possible only because individual males take over the care of some of the nests.

Other species of small waders nesting in the arctic of North America appear not to vary their reproductive effort from year to year, but always lay one clutch of four large eggs. The laying of a single clutch of four is the mode of breeding found among most calidrine sandpipers, whose clutch-size and number of nests most likely are adapted to the average summer conditions in habitats that vary little from year to year in the duration of snow cover or productivity of the tundra. Unlike the Sanderlings, the other Calidris sandpipers (Knot C. canutus, Purple Sandpiper C. maritima, Baird's Sandpiper C. bairdii, White-rumped Sandpiper C.fuscicollis) that breed on Bathurst Island have larger eggs and apparently are species adapted to average summers. With the possible exception of the Knot, these species are uncommon to rare breeders on Bathurst Island where Sanderlings evidently fare much better than other scolopacids. White-rumped Sandpipers apparently have failed to breed successfully there during three successive seasons (1968-1970).

No single breeding strategy appears best for all arctic waders, because in runs of average years over much of the arctic the species that lay only one clutch would probably be more successful in breeding than would single-brooded Sanderlings with their small eggs, which conceivably produce young less likely to withstand food shortages just after hatching than the better-provided young of other waders. In exceptionally good years the adaptable species such as the Sanderlings should have a greater success by leaving two or three times as many young per female, compared to the other waders. Conceivably the Sanderlings also do better in very bad years, when few or no young are raised, by incurring less mortality to the laying females, because their small eggs would cost the females little to produce, though the relationship between food resources and the survival of laying females, as well as small young, remains largely obscure. There is some evidence that in poor years some female Sanderlings lay no more than a single clutch. One latenesting female on Bathurst Island in 1968 showed only four ruptured follicles, and this was 
in a year when onset of many nestings was generally delayed by a persistent snow cover (Parmelee 1970: 116).

The active role that the female Sanderling takes in courtship behaviour is probably related to the laying of more than one clutch in a season. In contrast to most of the sandpipers that lay a single clutch, the female Sanderling has an aerial display similar to that of the male, and she also initiates the copulatory sequences by an active display at a precopulatory scrape (Parmelee 1970: 111-112). This behaviour probably reflects an intense competition among females for males. The female that attracts the attention of more than one male may leave more than one clutch to be incubated by her mates, besides raising a brood herself.

Regarding the delay in onset of incubation, a male might be most likely to succeed in breeding if he began immediately to incubate the first clutch that he had fathered. But an early-mating male that had inseminated a female for her first clutch might double the number of his offspring in a season if he delayed incubation for a few days and remained with his mate until she had laid a second set of eggs. The risk to a male (of losing eggs to bad weather or to predation) would probably be much smaller than would be his potential gain (doubling of his reproductive output) by continuing to consort with the female in favourable years, though in unfavourable years his gain would be negligible.

Most calidrine waders studied to date are monogamous and as a rule lay but a single clutch per year. The males of a few, namely White-rumped Sandpipers and Pectoral Sandpipers Calidris melanotos, evidently are polygamous or promiscuous, and the females of these species incubate the eggs and later care for the brood without male assistance. The evolutionary origin of the Sanderling breeding system (multiple clutches and, probably, occasional polyandry) cannot be traced with present knowledge, but one strong possibility is that it had its beginning in a calidrine system in which the birds were monogamous and had a single clutch per pair. In ancestral populations there might simply have been a tendency for the female to leave the nesting area for long periods while the male incubated. Incubating Sanderlings of either sex leave the nest unattended when they go off to feed, occasionally for surprisingly long periods. Even in those monogamous waders e.g. Stilt Sandpiper Micropalama himantopus, that share equally the duties of incubation, the bird not on the nest may remain away for hours at a time, perhaps thereby making the nest less conspicuous to predators and allowing the bird to seek better feeding areas (Parmelee et al. 1967: 223). In some calidrine waders the female may be able to lay again following the early loss of a clutch (Holmes (1966) suggests this for the occasional late clutches in Dunlin) and waders with small eggs are more likely to re-nest under those conditions. With a weakening of the pair bond associated with the male taking over the role of incubation and ignoring his mate, the female would be free to nest again. Multiple nestings would probably lead to selection for polyandrous mating in seasons of favourable weather, because females that could leave more than one clutch in the care of a male might leave proportionately more offspring than females that did not. Females should be polyandrous when they lay three clutches, as they can incubate but one, and they may be polyandrous with two clutches if non-incubating females incur less risk of mortality than incubating females. Two observations suggest behaviour consistent with the idea of sexual selection in female Sanderlings for courting more than one mate: adult threesomes are common, and the intrusions by adults near the the nest where a male was incubating were "astounding" in number (Parmelee 1970:130). Possibly some intruders were laying females attempting to cuckold the male away to mate and incubate their own late clutches.

In birds in which parental care is mainly in the hands of the male, such as some northern waders, we predict that under certain circumstances selection might favour serial polyandry among females. Most of the documented instances of polyandry in birds are of precocial birds (Lack 1968, Orians 1969). Perhaps a reason why polyandry has more 
often been selected for in precocial than in altricial birds is that parental care involves less risk of energy exhaustion or mortality of the father, as the young precocial birds feed themselves from an early age. At any rate, the " basic attributes of maleness and femaleness " assumed by Orians (1969: 595) do not universally include selection against males that are better parents to their offspring than are the females.

\section{ACKNOWLEDGMENTS}

The Canadian National Museum of Natural Sciences and the Canadian Polar Continental Shelf Project, Department of Energy, Mines and Resources, financed expeditions to Bathurst Island in 1968-1970. Financial assistance for transportation to and from Bathurst Island was provided by a faculty research grant-in-aid (NSF GU-2225 Institutional Grant No. 40) at Kansas State Teachers' College in 1969 and by G. M. Sutton in 1970 . The study of the Sanderling in arctic Canada was initiated in 1966 through a research grant-in-aid (GB-4904) from the National Science Foundation to Parmelee.

S. D. MacDonald, H. F. Mayfield, and P. S. Taylor assisted the field studies in 1970 . C. S. Adkisson, W. D. Graul, R. T. Holmes, W. R. Siegfried, D. C. Smith, and R. W. Storer thoughtfully criticised the manuscript, and it was typed by $M$. Madison. The photographs and photomicrographs were taken by L. P. Martonyi, and were lettered by M. Lackey. Reproduction of the photographs was supported by NSF GB-29017X to R.B.P.

\section{SUMMARY}

Sanderlings on Bathurst Island in the Canadian arctic have two patterns of incubation. At some nests the eggs are covered soon after the fourth egg has been laid and at others incubation is delayed for 5-6 days. Because the delay is about the same time required to lay a second clutch and because a single individual alone incubates at any one nest, we suspected that Sanderlings might normally lay two clutches in a season, the male caring for one brood and the female for the other.

Histological and gross examination of the ovaries of two females taken as the birds began incubation showed eight freshly ovulated follicles in each female. The size gradation and histological appearance of the follicles indicated that two clutches of four eggs each had been laid within 8-10 days by a single female. The ovary of one female had additional large yolky follicles, suggesting a physiological capability of further ovulations.

Field conditions in the arctic summer are highly variable, and the small eggs and the rapid sequence of broods of Sanderlings may be breeding adaptations that permit them to multiply the traditional wader clutch of four eggs by 2 or 3 in favourable years. Selection for mating systems characterised by brief pair bonds and by polyandry is expected in precocial birds where some broods are incubated and cared for by the male, but further field work is required to determine the precise mating system of Sanderlings.

\section{REFERENCES}

Bannerman, D. A. 1961. The birds of the British Isles. Volume X. Edinburgh and London.

BENT, A. C. 1927. Life histories of North American shore birds, Part I. Bull. U.S. natn. Mus. 142.

BENT, A. C. 1958. Life histories of North American blackbirds, orioles, tanagers, and allies. Bull. U.S. natn. Mus. 211.

BoyD, H. 1962. Mortality and fertility of European charadrii. Ibis 104: 368-387.

Davis, D. E. 1942. The regression of the avian post-ovulatory follicle. Anat. Rec. 82:297-307.

Dement'ev, G. P., Gladkov, N. A., \& Spangenberg, E. P. 1969. Birds of the Soviet Union, Volume III. IPST, Jerusalem.

Dominic, C. J. 1959. A study of the post-ovulatory follicle in the ovary of the domestic pigeon, Columba livia. J. zool. Soc. India 12: 27-33.

ERPINo, M. J. 1969. Seasonal cycle of reproductive physiology in the Black-billed Magpie. Condor 71: 267-279.

FELL, H. B. 1925. Histological studies on the gonads of the fowl. III. The relationship of the "luteal "cells of the ovary of the fowl to the tissue occupying the atretic and discharged follicle. Q. J1 microsc. Sci. 69: 591-609.

Hıц口ÉN, O. 1965. Zur Brutbiologie des Temminckstrandläufers, Calidris temminckii (Leisl.). Ornis fenn. 42: 1-5.

Holmes, R. T. 1966. Breeding ecology and annual cycle adaptations of the Red-backed Sandpiper (Calidris alpina) in northern Alaska. Condor 68:3-46.

Holmes, R. T. 1970. Differences in population density, territoriality, and food supply of Dunlin on arctic and subarctic tundra. In $\mathrm{A}$. Watson (Ed.), "Animal populations in relation to their food resources". Symp. Br. Ecol. Soc. Aberdeen, Scotland.

LACK, D. 1968. Ecological adaptations for breeding in birds. London.

OrIaNs, G. H. 1969. On the evolution of mating systems in birds and mammals. Am. Nat. 103: $589-603$.

Parmetee, D. F. \& MacDonald, S. D. 1960. The birds of west-central Ellesmere Island and adjacent areas. Bull. natn. Mus. Can. 169. 
Parmelee, D. F., Stephens, H. A., \& Schmidt, R. H. 1967. The birds of southeastern Victoria Island and adjacent small islands. Bull. natn. Mus. Can. 222

ParmeleE, D. F. 1970. Breeding behavior of the Sanderling in the Canadian high arctic. Living Bird 9: $97-146$.

PAyne, R. B. 1966. The post-ovulatory follicles of blackbirds (Agelaius). J. Morph. 118: 331-351.

PAYNE, R. B. 1969 . Breeding seasons and reproductive physiology of Tricolored Blackbirds and Redwinged Blackbirds. Univ. Calif. Publs Zool. 90.

Pitelka, F. A. 1959. Numbers, breeding schedule, and territoriality in Pectoral Sandpipers of northern Alaska. Condor 61: 233-264.

Schönwetrer, M. 1966. Handbuch der Oologie, Band I. Berlin.

STout, G. D. (Ed.) 1967. The shorebirds of North America. New York.

D. F. Parmelee, Department of Ecology and Behavioral Biology and fames Ford Bell Museum of Natural History, University of Minnesota, Minneapolis, Minnesota 55455, U.S.A.

R. B. Payne, Department of Zoology and Museum of Zoology, University of Michigan, Ann Arbor, Michigan 48104, U.S.A. 